\title{
Mushrooms and Truffles: Historical Biofactories for Complementary Medicine in Africa and in the Middle East
}

\author{
Hesham El Enshasy, ${ }^{1,2}$ Elsayed A. Elsayed, ${ }^{3,4}$ Ramlan Aziz, ${ }^{1}$ and Mohamad A. Wadaan ${ }^{3}$ \\ ${ }^{1}$ Institute of Bioproduct Development (IBD), Universiti Teknologi Malaysia (UTM), Skudai, 81130, Johor Bahru, Johor, Malaysia \\ ${ }^{2}$ City of Scientific Research and Technology Application, New Burg Al Arab, Alexandrai 21934, Egypt \\ ${ }^{3}$ Bioproducts Research Chair, Department of Zoology, Faculty of Science, King Saud University, Riyadh 11451, Saudi Arabia \\ ${ }^{4}$ Department of Natural and Microbial Products, National Research Centre, Dokki, Cairo 12311, Egypt
}

Correspondence should be addressed to Hesham El Enshasy; henshasy@ibd.utm.my

Received 22 April 2013; Accepted 1 October 2013

Academic Editor: Imed Eddine Hassen

Copyright (C) 2013 Hesham El Enshasy et al. This is an open access article distributed under the Creative Commons Attribution License, which permits unrestricted use, distribution, and reproduction in any medium, provided the original work is properly cited.

\begin{abstract}
The ethnopharmaceutical approach is important for the discovery and development of natural product research and requires a deep understanding not only of biometabolites discovery and profiling but also of cultural and social science. For millennia, epigeous macrofungi (mushrooms) and hypogeous macrofungi (truffles) were considered as precious food in many cultures based on their high nutritional value and characterized pleasant aroma. In African and Middle Eastern cultures, macrofungi have long history as high nutritional food and were widely applied in folk medicine. The purpose of this review is to summarize the available information related to the nutritional and medicinal value of African and Middle Eastern macrofungi and to highlight their application in complementary folk medicine in this part of the world.
\end{abstract}

\section{Introduction}

From early stages of civilization, desert macrofungi in forms of mushrooms and truffles have been used as food and medicine. Originally, these types of organisms were associated with Mediterranean region and were first recorded as poem in Egyptian temples as follows: "Without leaves, without buds, without flowers: yet they from fruit; as a food, as a tonic, as a medicine: the entire creation is precious." Thus, macrofungi were considered as food and medicine for royalty, and that no normal citizens were allowed to consume this precious food. During Greek and Roman eras, they were imported from Libya and sold in southern part of the European continent [1]. In the southern part of African continent, the nomadic people of Kalahari Desert used truffles for millennia [2].

Mushrooms are visible to the naked eye as they grow above the earth, whereas truffles grow underground in depth between 5 and $10 \mathrm{~cm}$. Truffles are usually collected by specialists who have special skills and experience to explore this type of flora. Sometimes, truffle collectors use some animals such as pigs and dogs to discover this type of underground fungus. This is based on their high sensitivity to the characteristic truffle volatile compounds. Traditionally, mushrooms and truffles are taken as type of precious food and consumed either raw or cooked. In addition, they have been also applied as main component of folk medicine. This was based on the fact that they are rich source for proteins, amino acids, fatty acids, fiber, minerals, vitamins, terpenoids, sterols, flavor compounds, and carbohydrates as reported by many authors [3-5].

In general, not all types of macrofungi are able to grow in the harsh environmental conditions of desert. The term "Desert Macrofungi: Mushrooms and Truffles" is related to the nature and distribution of those species which can grow under arid and semiarid conditions. Thus, the geographical distribution of desert truffles in Africa and Middle East is related to countries around the Mediterranean such as Morocco, Algeria, Tunisia, Libya, Egypt, and Israel in addition to the countries of the Arabian Peninsula such as Jordan, Syria, Saudi Arabia, Iraq, Bahrain, and Kuwait. However, some types of desert truffles were also found in South Africa 
and Botswana [6]. Generally, the growth of desert truffles requires an annual rainfall range between 50 and $380 \mathrm{~mm}$. In North Africa, good yields of truffle are usually obtained if the rainfalls range between 70 to $120 \mathrm{~mm}$. In addition, the time, quantity, and distribution of the rainfall play an important role in the quality of desert macrofungus growth. For example, to obtain good truffles in North African and Middle Eastern regions, it needs to get rainfall no later than the beginning of December whereas, in southern Europe it should not be later than the beginning of October [7].

For centuries, it was proposed that most of the wild macrofungi are not cultivable. However, with the increased knowledge of mushroom and truffles physiology, nowadays, it is possible to cultivate many types of macrofungi. Mushrooms were successfully cultivated in green houses and in submerged culture fermentation. Whereas, based on the symbiotic behavior of truffles as typical ectomycorrhiza, they were cultivated in soil with their host plant in truffle green houses in semiarid area $[6,7]$. With the rapid growth of bioprocess technology industries, it was possible to cultivate many macrofungi in submerged culture under fully controlled conditions to produce the desired biotherapeutic compounds in high concentrations, in shorter production time, and under fully sterile conditions according to cGMP [8-10].

This review outlines the current status of knowledge on the macrofungi bioactive compounds and their applications in complementary and alternative medicine in different African and Middle Eastern cultures.

\section{Type and Identification}

Different types of desert epigeous macrofungi (mushrooms) and hypogeous macrofungi (truffles) are considered as natural flora in the Middle East and the African desert. Mushrooms are characterized by their distinguished structure of stalk and their fragile and soft feature. Truffles have no stalk and no gills with firm, dense, and woody feature. The name truffles/terfezia comes from the word "Terfass," which is an Arabic word describing hypogeous desert fungus. Truffles are also known locally in North Africa and Arabian Peninsula under other names such as "Al-Kamaa" or "Al-Faga." Taxonomically, truffles are ascomycetes fungi belonging to the genus Tuber, the family Tuberaceae, and the order Pezizales [11] and are distributed in six pezizalean families: Glaziellaceae, Discinaceae, Morchellaceae, Helvellaceae, Tuberaceae, Pezizaceae, and Pyronemataceae [12]. In general, most of known desert truffles species belong to genera such as Terfezia, Delastreopsis, Balstonia, Delastria, Leucangium, Mattirolomyces, Phaeangium Picoa, Tirmania, and Tuber [6]. Ecologically, desert truffles are symbiotic microorganisms and they establish ectomycorrhizal symbiotic relationship with species of Helianthemum genus. Therefore, the distribution of desert truffles is limited not only by the environmental conditions but also by the availability of the host plant. For example, in Arabian Peninsula, only three types of truffles belonging to Terfezia, the two black-dark brown colored truffles Terfezia claveryi and Terfezia boudieri (known locally as Ikhlasi), and the white-cream colored truffle belonging to Tirmania nivea (known locally as Zubaidi) are available in this region [13]. In addition, another species of truffle Phaeangium lefebvrei is commonly known as bird truffle "Faga Al toyoor or Hopper" and is mainly consumed by birds. In North Africa, in addition to the previous local names, many other names are also given for truffles such as "Nabat Al Radh, asqal, Bidat El Ardh and Banat Ober” [14].

Mushrooms spread in wide area in Africa and Middle East. The most common types of mushrooms belong to Agaricus and Pleurotus sp. (Basidiomycetes). In North Africa, different types of Pleurotus sp. were found only for few days after rainy season. Based on its morphological structure and physiology, mushrooms are more sensitive to high temperature and dry conditions compared to truffles. The tropical and subtropical regions of Africa are characterized by higher mushroom diversity compared to North Africa. Table 1 shows some examples of different types of mushrooms and truffles in Africa and Middle East.

\section{Nutritional Value}

Desert macrofungi are rich source of different types of essential nutrients, and thus their nutritional value and chemical profile were studied and reviewed by many authors [15]. The chemical analysis of desert truffles showed that the dry matter is composed of up to $60 \%$ carbohydrates, $20-27 \%$ protein, $3-7.5 \%$ fat (unsaturated and saturated fatty acids), $7-13 \%$ fiber, and 2-5\% ascorbic acid [12]. Another study for chemical profiling of three Iraqi truffles (Terfezia claveryi, Tirmania nivea, and Tirmania pinoyi) showed that the carbohydrate concentration in dry matter ranged between 16.6 and $24.8 \%$, protein content ranged from 8.1 to $13.8 \%$, phosphorus from 9.7-25.5\%, and ash 4.9-5.9\% [16]. Another research showed also that the chemical composition of truffle is highly strain specific and the white desert truffle Tirmania nivea (Zubaidi) was higher in protein, fat, and crude fiber content compared to other two types of desert truffles belonging to black truffle group (Gibeah and Kholeissi) [17]. However, the same study showed also that all essential amino acids were present in all three truffles including the sulphur amino acids (methionine, cysteine, tryptophan, and lysine) which are usually the limiting amino acids in many foods of plant origin. In addition, different studies demonstrated also that truffles are rich source of essential minerals such as $\mathrm{Si}, \mathrm{K}$, $\mathrm{Na}, \mathrm{Ca}, \mathrm{Mg}, \mathrm{Mn}, \mathrm{Fe}, \mathrm{Al}, \mathrm{Cu}$, and $\mathrm{Zn}$ [15].

Unlike truffles, the dry content of mushrooms is usually in the range between 60 and $140 \mathrm{~g} / \mathrm{kg}$. In most types of mushrooms, carbohydrates and crude proteins are the main two components. The composition of mushroom fruit bodies is very rich with carbohydrates, and its concentration is ranging between 20 up to more than $70 \%$ of the dry weight and is highly dependent on mushroom strain. Glucose, mannitol, and trehalose, their derivatives and oligosaccharides, are the main polysaccharides and share very low percentage in fruit body dry weight. Unlike plants which store polysaccharide in the form of starch, mushrooms store polysaccharides in the form of glycogen and usually contribute to about $5-10 \%$ of dry matter [5]. Chitin, a water insoluble polysaccharide, 
Table 1: Some examples of different types of wild macrofungi in Africa and in the Middle East region.

\begin{tabular}{|c|c|c|}
\hline & Countries & References \\
\hline \multicolumn{3}{|l|}{ Type of truffle } \\
\hline Terfezia boudieri Chatin & Libya & {$[72]$} \\
\hline Terfezia claveryi & Saudi Arabia, Bahrain, Iraq, Egypt, and Jordan & {$[29,45]$} \\
\hline Terfezia pfeilii & South Africa & {$[86]$} \\
\hline Terfezia sp. & Tunisia & {$[87]$} \\
\hline Tirmania nivea & Saudi Arabia, Morocco, Bahrain, Egypt, and Kuwait & $\begin{array}{c}{[13,16,73,} \\
88]\end{array}$ \\
\hline Phaeangium lefebvrei & Bahrain, Saudi Arabia, Egypt, and Kuwait & {$[14]$} \\
\hline $\begin{array}{l}\text { Choiromyces echinulatus } \\
\text { (Eremiomyces echinulatus) }\end{array}$ & South Africa & $\begin{array}{l}{[86]} \\
{[82]}\end{array}$ \\
\hline Picoa juniper & Tunisia & [89] \\
\hline Picoa lefebvrei & Tunisia & [89] \\
\hline Kalaharituber pfeilii & South Africa, Botswana & {$[82]$} \\
\hline \multicolumn{3}{|l|}{ Types of mushrooms } \\
\hline Pleurotus sp. & Almost in all African and Middle Eastern countries & {$[51]$} \\
\hline Agaricus sp. & Almost in all African and Middle Eastern countries & \\
\hline Lentinus sp. & Cameroon, Nigeria & {$[90]$} \\
\hline $\begin{array}{l}\text { Russula sp. } \\
\text { Cantharellus sp. } \\
\text { Afroboletus luteolus }\end{array}$ & Madagascar, Zimbabwe & {$[91,92]$} \\
\hline Termitomyces sp. & & {$[93]$} \\
\hline Lactarius sp. & Zambia, Zimbabwe, Mozambique, Tanzania, Zaire, and Benin & {$[94]$} \\
\hline Cantharellus sp. & & {$[95]$} \\
\hline Amanita zambiana & & \\
\hline Schizophyllum commune & Ethiopia & {$[96]$} \\
\hline $\begin{array}{l}\text { Chlorophyllum sp. } \\
\text { Phlebopus sp. }\end{array}$ & Burkina Faso & {$[97]$} \\
\hline
\end{tabular}

contributes to up to $80-90 \%$ of mushroom cell wall in addition to other components such as hemicelluloses and pectin [18]. Mushrooms contain also high content of insoluble fiber which also increases its nutritional value. On the other hand, mushrooms are very rich in proteins and usually comprise about $30 \%$ of dry weight. Protein distribution is usually changeable during the fungal development. It was reported that, for the widely distributed oyster mushroom (Pleurotus ostreatus), the highest crude protein content of about $36 \%$ with highest digestibility (92\%) is mainly found in fungal cap of diameter ranging between 5 and $8 \mathrm{~cm}$ [19]. In addition to the high fungal protein content, the proportion of essential amino acids makes it of higher nutritional value compared to plant proteins [5]. The mushroom lipid content ranges between 2 and $6 \%$ of dry weight. The polyunsaturated linoleic acid, the monounsaturated oleic acid, and the saturated palmitic acids are the main components of mushroom fatty acids. Other branched chain acids and hydroxyl fatty acids are also present in some mushrooms but in very low concentrations $[20,21]$. Mushrooms also include ash (5-12\% of dry matter) and are rich in essential elements such as sodium, potassium, calcium, magnesium, phosphorus, and sulfur. Moreover, mushrooms also include many essential trace elements such as manganese, cupper, and selenium. The presence of chromium and selenium in acceptable concentrations (few mg per kg dry matter) increases the nutritional value of mushrooms and is considered as potential source of organic selenium/chromium in diets and food supplements [5].

\section{Volatile Organic Compounds}

In general, macrofungi are characterized by their ability to produce wide range of volatile compounds which gives the characteristic flavor of this group of organisms. The characteristic aroma compounds of fruiting bodies are often used for strain nomenclature in both Latin and local names to indicate special aromatic characteristics. For example, attributes like butyrace- (butter like), odor-losm- (fragrant), delicat- (delicious), olid- (ambrosial, suav- (sweet), and nidoros- (pungent) point out certain tastes and aromas [22].

Truffles are typical ectomycorrhizal fungi and thus must grow in association with host plant. The hypogeous fruiting bodies of this type of organisms are characterized by their strong aroma which helps the truffle hunters to find them in the soil. This complex aroma comes from easily evaporated low molecular weight carbon compounds 
which have common name as volatile organic compounds (VOCs). These compounds play crucial ecological role in the recognition between the fungus and the host plant and also regulate the symbiosis process. In addition, these compounds play another role in the interaction between the truffles and nonhost plant as well. Nowadays, more than 200 VOCs and many nonvolatile compounds have been isolated and identified from truffles fruiting bodies. Truffles VOCs include fatty acids, terpenoids, aromatic compounds, and sulfur containing compounds [23]. On the other hand, mushroom volatile flavors and VOCs are one of the fungal characteristics which sometimes determine their commercial value. In general, the flavor and special aroma of certain mushrooms are usually a combination of different VOCs. The chemical profile of volatile compounds of $P$. ostreatus includes $\mathrm{C}_{8}$ compounds such as oct-1-ene-3-ol, octan-3-ol, octan-3one, octanal, oct-1-en-3-one, and octan-1-ol in addition to benzaldehyde (almond odor), benzyl alcohol (sweet spicy odor), and monoterpenes like linalool and linalool oxide. These all together make the characteristic aroma and pleasant flavor of this mushroom [24]. In other mushrooms like Termitomyces schimperi, which is common fungus in many African countries, the VOCs of fresh fruiting bodies include more than twenty-four compounds. They include oct-1-en-3ol, 2-phenylethanol, and hexanal. It was also interesting that these VOCs were almost the same in both of caps and stems of this fungus [25].

However, these characteristic fungal VOCs are important during fungal life cycle, not only to increase their market value but also to contribute to the nutritional and medicinal values of macrofungi.

\section{Functional Chemical Compounds of Health Value}

5.1. Antioxidants. Macrofungi are well known to contain different bioactive polyphenolic compounds. These compounds act as effective antioxidants based on their excellent ability to scavenge free radicals and act as reducing agents. Thus, it was proposed by many authors that there are strong correlations between the antioxidant activities of certain type of fungi and the type and concentration of polyphenolic compounds. Different groups of desert truffles and mushrooms showed strong antioxidant activities based on their high polyphenolic and ergosterol contents [13]. In the study of Villares et al. [26], different types of bioactive organic compounds showing antioxidant activities were isolated from Tuber sp. These include, ergosterol such as ergosteryl ester, wide range of phenolic acids such as gallic, homogentisic, protocatechuic, $p$-hydroxybenzoic, and $o$ - and $p$-coumaric acids, and other phenolic derivatives such as 3,4-dihydroxybenzaldehyde. The study of Al-Laith [13] showed also that the famous white desert truffle $T$. nivea showed high antioxidant activities. It was claimed that the fungal antioxidant capacity is attributed to the presence of various chemicals such as ascorbic acid, carotenoids, esterified phenolics, and free- and nonflavonoid phenolics and flavonoids. Another research showed that the small truffle Picoa lefebvrei is also among the most attractive mushrooms in folk medicine based on its high antioxidant properties [27].

5.2. Antimicrobial Activity. Since the early 20th century, fungi are known for their highly potent antimicrobial secondary metabolites. However, the antibacterial and antiviral activities of desert truffles were first studied in 1980s by Al-Marzooky [28] who investigated the in vitro biological activities of all aqueous polar and nonpolar extracts of $T$. claveryi. This extract exhibited good wide spectral antimicrobial activities especially against the trachoma causing disease Chlamydia trachomatis, stomach ulcer, and open cut. Another research demonstrated that the use of aqueous extract of Terfezia claveryi inhibited the growth of pathogenic bacteria such as Staphylococcus aureus [29] and Pseudomonas aeruginosa [30]. The antimicrobial activity of Terfezia was due to the production of small molecular weight peptide antibiotics [29]. In addition to the wide spectrum antibacterial activities, Terfezia extract possessed also antiviral activities [16]. Another research done by Dib-Bellahouel and Fortas [31] showed also that the ethyl acetate extract of Tirmania pinoyi exhibited potent antimicrobial activities against the G+ve bacteria B. subtilis and S. aureus. These all together make mushrooms and truffle important candidates in complementary medicine [32].

5.3. Immunomodulators and Antitumors. Immunomodulators or Biological Response Modifiers (BRMs) are compounds capable of interacting with the immune system to upregulate or downregulate specific aspects of the host response. Some of these compounds exhibiting also anticancer activities were isolated from different types of macrofungi $[8,33]$. Different types of BRM were applied as immunotherapeutic agents and showed significant activity as potent anticancer compounds in both in vitro and in vivo models [34-36]. Of the two main types of macrofungi, mushrooms are a common source of producing this type of compounds naturally. BRMs were isolated from different mushrooms parts such as fruiting bodies, stalk, spores, and mycelium in addition to fermentation broth when cultivated in submerged culture. In some research, BRMs were applied in combination with conventional chemo- and radiotherapy during cancer treatment to increase their efficiency. In general, according to their chemical structure, mushroom BRMs were classified into four main categories: lectins, terpenoids, polysaccharides and their peptides, and fungal immunomodulator proteins (Fips) [8]. Since the discovery of the potent anticancer polysaccharide lentinan (derived from Lentinus edodes) by Ikekawa and his group in late 1960s, mushrooms polysaccharides became one of the most interesting topics of research for the discovery and development of new anticancer drugs. [37]. Most of the known mushroom bioactive polysaccharides have various branching types of $(1 \rightarrow 3)$ - and $(1 \rightarrow 6)-\beta$-D-glucan and polysaccharide protein complex [38]. However, the biological activity of mushroom polysaccharides is highly dependent on the length and branching of the chain, chain rigidity, and helical conformation [39]. Pleuran (from Pleurotus ostreatus), Lentinan (from Lentinus edodes), Grifolan (from Grifola frondosa), 
Krestin-PSK (from Polystitcus versicolor), and Scleroglucan (from Sclerotina sclerotiorum) are the most famous bioactive polysaccharides from mushroom origin [8, 40-44].

5.4. Other Medical and Cosmeceutical Applications. The medicinal value of African and Middle Eastern macrofungi is not limited to the above mentioned applications. It was also reported that both truffles and mushrooms have also potential applications as hepatoprotective, cholesterol and sugar lowering, and anti-inflammatory agent $[15,32,38,42]$. For example, the extract of the known desert truffle ( $T$. claveryi) showed powerful hepatotoxic activity against the known hepatotoxin carbon tetrachloride [45]. In addition to the known and the well-studied medical applications, different mushroom extracts were applied in cosmetic products such as moisturizers, skin antifade and antiaging agents, skin revitalizers, and whitening cream [46].

\section{Therapeutic Values and Ethnomycological Applications}

The total number of mushrooms on earth is expected to be 140,000 , among which only $10 \%$ (about 14,000 ) is known [ 47 , 48]. It is strongly believed that a large number of the unknown species to be discovered may be present in Africa. Generally, there is little or no information about the therapeutic and medicinal uses of these mushrooms in Africa. Primarily, this may be attributed to the fact that this information is scattered in a multitude of sources which are not easily accessible to the international English-speaking community [49]. Secondly, unlike Japan and China, where the knowledge on medicinal applications of edible mushrooms has been documented [50], most of the information on indigenous applications of African mushrooms had been passed orally from one generation to the other [51]. Nowadays, the available knowledge on the medicinal applications of African mushrooms comes from elder people selling those [52] as well as from some ethnobotanical monographs summarizing data for a particular region of the world [53-56].

The variation of climatic conditions within the continent is directly reflected on the prevalence of mushrooms in different geographical regions. Accordingly, medicinal applications may differ not only between different countries, but also between different ethnic groups inhabiting the same country. Mushrooms belonging to species of Termitomyces, Pleurotus, Lentinus, Lenzites, Trametes, Ganoderma, Pycnoporus, Coriolopsis, and Calvatia have been reported to be used in folk medicine in Nigeria $[48,57,58]$. On the other hand, mushrooms of the species Termitomyces, Agaricus, Boletus, Pleurotus, Cantharellus, Macrolepiota, Ganoderma, and Geastrum have been reported in Tanzania [59,60]. Moreover, Kamatenesi-Mugisha and Oryem-Origa [61] have reported that the ethnomycological application of toadstool mushrooms from the family Tricholomataceae has been documented in western Uganda. In Burkina Faso, the application of the mushroom Parkia biglobosa has been also reported [62].
Mushrooms have been used in sub-Saharan Africa during the Paleolithic period (7000-9000 B.P.), where their application has been traditionally related to mysticism [57, 63]. Historically, the first reports record the application of mushroom as a hallucinogenic agent by the people of the Yoruba tribe in Nigeria [64]. Additionally, Oso [52] reported that the Yoruba traditional doctors applied a medicinal preparation of Termitomyces microcarpus for the treatment of gonorrhea. The preparation was administered orally by pounding a large quantity of the mushroom fruiting bodies with the pulp of the fruit Cucurbita pepo Linn., the leaves of Cassia alata Linn., and other ingredients. They also used oral administration of Calvatia cyathiformis in a ground form with other herbal ingredients to treat a disease known in Yoruba as Masomaso. This disease is believed to prevent pregnancy, in which the woman begins to discharge effluvium through her vagina. Additionally, they used C. cyathiformis ground with Daldinia concentrica as a remedy for leucorrhoea, where the patient woman washes her vagina at predetermined intervals.

Recently, Akpaja et al. [51] and Ayodele et al. [65] reported different ethnomycological applications of mushrooms used by the people of the Igbos in South East and the Igalas in North central Nigeria. They reported that the Igbo and Igala tribes have used Pleurotus tuberrigium to overcome headache, stomach pain, fever, cold and constipation; Lentinus squarrosulus for treating mumps and heart diseases; T. microcarpus for treating gonorrhea; Calvatia cyathiformis for treating leucorrhea and bareness; Ganoderma lucidum for treating arthritis and neoplasia; G. resinaceum to reduce blood sugar level (hypoglycemic) and to overcome liver diseases (hepatoprotector); G. applanatum used as an antioxidant and anti diabetes; Volvariella volvaceae as an antibiotic and antineoplastic; and Daldinia concentrica for treating stomach ulcers and skin diseases.

Mdachi et al. [60] reported that in Tanzania and most African countries, some wild mushrooms have been used in traditional medicine. They also reported that in some rural areas of Tanzania, a mushroom soup is provided to mothers after child delivery to enhance fast recovery, while other mushroom species are used as medicines for stomach and heart diseases. In addition, Ganoderma species has been used to treat sick cows, while some puffball mushrooms are traditionally used for wound healing in the Kilimanjaro region of Tanzania.

In 2007, Kamatenesi-Mugisha and Oryem-Origa [61] investigated the effect of medicinal plants used by traditional medical practitioners in inducing labor, namely, uterine contractions, during childbirths in and around Queen Elizabeth Biosphere Reserve in Uganda. They found that native women use toadstool mushroom from the family Tricholomataceae to induce labor during childbirth by enhancing uterine contractions.

Moreover, Beiersmann et al. [62] reported that young mothers in Burkina Faso use mushroom to treat a respiratory distress syndrome, locally known as Dusukun yelema, of which $80 \%$ are due to malarial acidoses. They apply the ashes of burned mushroom (Parkia biglobosa) onto the child's chest. Table 2 summarizes some of the ethnomycological 
TABle 2: Ethnomycological applications of mushrooms in different African countries.

\begin{tabular}{|c|c|c|c|}
\hline Mushroom & Country & Ethnomycological applications & Reference \\
\hline Pleurotus tuber-rigium & Nigeria & Treatment of headache, cold, fever, stomach ache, and constipation & \\
\hline Lentinus squarrosulus & Nigeria & Treatment of mumps and heart diseases & \\
\hline Termitomyces microcarpus & Nigeria & Treatment of gonorrhea & \\
\hline Calvatia cyathiformis & Nigeria & Treatment of leucorrhea, bareness, and hiccups & \\
\hline Ganoderma lucidum & Nigeria & Treatment of arthritis and neoplasia & \\
\hline G. resinaceum & Nigeria & Lowering blood sugar level and protecting liver cells & {$[48]$} \\
\hline G. applanatum & Nigeria & $\begin{array}{l}\text { Antioxidant and used for lowering blood sugar level, as well as } \\
\text { antihypertensive }\end{array}$ & \\
\hline Schizophyllum commune & Nigeria & Treatment of diabetes & \\
\hline Volvariella volvaceae & Nigeria & Antibiotic and antineoplastic & \\
\hline Auricularia auricular & Nigeria & Treatment of hemorrhoids and hemoptysis & \\
\hline Daldinia concentrica & Nigeria & $\begin{array}{l}\text { Treatment of stomach ulcer and upset, skin disease, and whooping } \\
\text { cough and prevention of excessive growth of fetus to ease the delivery }\end{array}$ & \\
\hline Polyporus officinalis & Nigeria & Treatment of hernia, cough, and catarrh & \\
\hline $\begin{array}{l}\text { Soup of different wild } \\
\text { mushrooms }\end{array}$ & Tanzania & Promote quick recovery of mothers after childbirth & {$[56]$} \\
\hline Ganoderma spp. & Tanzania & Treatment of sick cows & {$[60]$} \\
\hline Puffball mushrooms & Tanzania & Wound healing & {$[60]$} \\
\hline Termitomyces microcarpus & Tanzania & Health promoter and inducer of breast lactation & [59] \\
\hline Termitomyces titanicus & Tanzania & $\begin{array}{l}\text { Treatment of abdominal pain, stomach ache and ulcers, and } \\
\text { constipation }\end{array}$ & {$[59]$} \\
\hline Toadstool mushroom & Western Uganda & Induce labor during childbirth & {$[61]$} \\
\hline Parkia biglobosa & Burkina Faso & Treat respiratory distress syndrome resulting from malarial acidoses & {$[62]$} \\
\hline
\end{tabular}

applications of mushrooms reported in different African countries.

In a recent study, Tibuhwa [59] explored the dietary, therapeutic, and ethnomycological applications of wild mushrooms in communities living around Ngorongoro and Serengeti National Park in Tanzania. The study aimed at exploring the actual taxonomy knowledge of the Kurya and Masai tribes and at developing a baseline data which can contribute to establishing mushroom traditional uses depository. The study revealed that most of the Kurya tribe people use wild mushrooms as either foodstuff or as tonic. Among the mushrooms used for therapeutic applications, they used Termitomyces titanicus, T. letestu, T. eurhizus, and T. auranticus for the treatment of different intestinal problems, for example, pain, ulcer, constipation, and stomach ache. Termitomyces microcarpus was found to be used as immune boosting agent and is given to sick people to speed up their recovery as well as lactating mothers. The study also revealed that both tribes have different manners in using the same mushroom. Table 3 summarizes some of the ethnomycological knowledge on mushroom utilization by both tribes.

Truffles are hypogeous fruiting bodies of the ascomycetous fungi living symbiotically with soil plant roots [66]. Truffle species have a wide range of host plant species, require a calcareous soil, and have different geographical distribution $[67,68]$. They have been found through Europe [69], especially in Italy, France, and Spain and throughout
China [70], Australia [71], North Africa and sub-Saharan countries $[72,73]$, and the Middle East $[14,74]$.

Truffles are widely appreciated as a costly delicacy as well as for their organoleptic properties, especially aroma [67]. Additionally, truffles have been used to promote health and to prevent and to treat several diseases. They have been reported to possess anti-inflammatory, immunosuppressing, and anticarcinogenic properties $[13,75]$, antioxidant properties [26, $76]$, and antimicrobial activities [29, 77, 78].

Truffles have been reported in many African countries [79-81]. Desert truffles have been traditionally used by the native people of the Kalahari in southern Africa for millennia $[2,82]$, as well as by the Saharan natives $[73,83,84]$. Truffles belonging to the species of Terfezia and Tirmania have been generally eaten by the native people of north Africa and the Middle East from prehistoric times. The Khoisan people (sometimes called the Bushmen or San) have used truffles from the species of Kalaharituber, Eremiomyces, and Mattirolomyces [82].

Contrary to mushrooms, less attention has been paid to the indigenous information about medicinal truffles in Africa. The available information comes from some amateurs and foreign tourists' documentation, as well as from knowledge accumulation passed orally from generation to the next [14]. Omer et al. [73] reported that desert truffles (Tirmania and Terfezia spp.) have been utilized in folk medicine for the treatment of ophthalmic diseases and as aphrodisiac agents. Moreover, the same truffles have been also reported to be used 
TABLE 3: Ethnomycological knowledge on mushrooms utilization by the Kurya and Maasai tribes around Ngorongoro and Serengeti National Park, Tanzania, modified from [59].

\begin{tabular}{|c|c|c|c|c|}
\hline Species & Kurya & Masai & Kurya & Masai \\
\hline Termitomyces microcarpus & Bitoghose & Not known & $\begin{array}{l}\text { Food: improve healthy to long-ill } \\
\text { people and lactating mothers }\end{array}$ & Not known \\
\hline T. titanicus & Lyugu & Ormambuli & $\begin{array}{l}\text { Food: tonic for various } \\
\text { gastrointestinal problems }\end{array}$ & $\begin{array}{l}\text { Few know it as tonic for various } \\
\text { gastrointestinal problems }\end{array}$ \\
\hline T. aurantiacus & Nyankobhiti & Ormambuli & Food: tonic for stomach aching & Not known \\
\hline T. clypeatus & Vihungumururyo & Ormambuli & Food & Not known \\
\hline T. eurhizus & Amanyegiswa & Ormambuli & Food & Not known \\
\hline T. le-testui & Lyugu & Ormambuli & Food & $\begin{array}{l}\text { Few know it as tonic for various } \\
\text { gastrointestinal problems }\end{array}$ \\
\hline T. mammiformis & Bitoghose & Ormambuli & Food & Not known \\
\hline T. umkowaan & Amughu & Ormambuli & Food & $\begin{array}{l}\text { Few know it as tonic for various } \\
\text { gastrointestinal problems }\end{array}$ \\
\hline T. tylerianus & Bitoghose & Ormambuli & Food & Not known \\
\hline T. striatus & Bitoghose & Ormambuli & Food & Not known \\
\hline Agaricus campestris & Bitoghose & Ormambuli & Food & Not known \\
\hline Macrolepiota procera & Binyankorogoto & Not known & Healing wounds & Not known \\
\hline Ganoderma boninense & Binyankorogoto & Not known & Treat wound and skin infections & Not known \\
\hline Geastrum saccatum & Uiborinyiti & Not known & $\begin{array}{l}\text { Subject bees into anaesthesia } \\
\text { state }\end{array}$ & $\begin{array}{l}\text { Subject bees into anaesthesia } \\
\text { state }\end{array}$ \\
\hline G. triplex & Uiborinyiti & Not known & $\begin{array}{l}\text { Subject bees into anaesthesia } \\
\text { state }\end{array}$ & $\begin{array}{l}\text { Subject bees into anaesthesia } \\
\text { state }\end{array}$ \\
\hline
\end{tabular}

in folk medicine in sub-Saharan Africa and Middle East to treat skin and eye diseases, for example, Trichoma [16, 28]. Traditionally, desert truffles have been used as folk medicine in the Arabian countries over two millennia without any known complications [85]. In these countries, boiled truffle water extract has been recommended by the Bedouins for the treatment of trachoma, one of the earliest recorded eye diseases by the World Health Organization.

Spiritually, the Khoisan hunters in the Kalahari desert believe that desert truffles (kuuste or n'xaba) counteract the effects of poisoned arrows in shot animals [82], and until the animal is confirmed to be dead, the hunter can take no food or drink other than water. This is due to the fact that they believe that if the archer eats food, the wounded animal will regain its health and escape. Moreover, the hunters keep a piece of kuuste to eat as an antidote in case of being accidently wounded by a poisoned arrow.

\section{Conclusions and Future Prospects}

Africa and Middle East are very rich regions of unique types of macrofungi. Both truffles and mushrooms of this area of the world produce wide variety of interesting bioactive compounds of high medical value and were used for millennium in the treatment of different diseases. The main drawbacks for their application in modern medicine and for production in industrial scales are based on four main facts. First, most of these types of organisms are not cultivable in green house and thus their availability is seasonal and highly affected by climate change. The second fact is the wide variability of the bioactive ingredient contents which are highly dependent on collection time, procedure, season, and environment. Third, based on the chemical composition of both of mushrooms and truffles, they have high capacity to accumulate high concentration of heavy metals and radioactive isotopes. Thus, special consideration should be taken into account when collected from polluted areas. The fourth fact is the lack of standard testing protocols to guarantee the quality and the efficacy of the fungal product. Thus, more research is required to solve the above mentioned problem to increase the use of wild macrofungus in medical applications. This will change in part the current medical practice using chemically synthesized compounds of many side effects.

\section{References}

[1] M. Honrubia, A. Morte, and A. Gutiérrez, "Las Terfezias. Un cultivo para el desarrollo rural en regions áridas y semi-áridas," in Truficultura. Fundamentos y técnicas, pp. 365-397, Ediciones Mundi-Presna, Madrid, Spain, 2007.

[2] J. M. Trappe, "Use of truffles and false truffles around the world," in Atti Secondo Congresso Internazionale sul Tartufo, Spolero, pp. 19-30, Comunitá Montana dei Monti Martani e del Serano, Spolero, Italy, 1990.

[3] H. A. Bokhary and S. Parvez, "Chemical composition of desert truffles Terfezia claveryi," Journal of Food Composition and Analysis, vol. 6, no. 3, pp. 285-293, 1993.

[4] M. A. Murcia, M. Martínez-Tomé, A. Vera et al., "Effect of industrial processing on desert truffles Terfezia claveryi Chatin 
and Picoa juniperi Vittadini): proximate composition and fatty acids," Journal of the Science of Food and Agriculture, vol. 83, no. 6, pp. 535-541, 2003.

[5] P. Kalač, "Chemical composition and nutritional value of European species of wild growing mushrooms: a review," Food Chemistry, vol. 113, no. 1, pp. 9-16, 2009.

[6] A. Morte, M. Honrubia, and C. Gutiérrez, "Biotechnologyand cultivation of desert truffles," in Mycorrhiza, pp. 467-483, Springer, Berlin, Germany, 2008.

[7] A. Morte, M. Zamora, A. Gutiérrez, and M. Honrubia, "Desert truffle cultivation in semiarid Mediterranean areas," in Mycorrhizas-Functional Processes and Ecological Impact, pp. 221-233, Springer, Berlin, Germany, 2009.

[8] H. El Enshasy, "Immunomodulators," in The Mycota: Industrial Applications, vol. 10, pp. 165-194, Springer, Berlin, Germany, 2010.

[9] Y.-J. Tang, L.-W. Zhu, H.-M. Li, and D.-S. Li, "Submerged culture of mushrooms in bioreactors-challenges, current stateof-the-art, and future prospects," Food Technology and Biotechnology, vol. 45, no. 3, pp. 221-229, 2007.

[10] E. Vamanu, "Biological activities of the polysaccharides produced in submerged culture of two edible Pleurotus ostreatus mushrooms," Journal of Biomedicine and Biotechnology, vol. 2012, Article ID 565974, 8 pages, 2012.

[11] K. O’Donnell, E. Cigelnik, N. S. Weber, and J. M. Trappe, "Phylogenetic relationships among ascomycetons truffles and the true and false morels inferred from $18 \mathrm{~S}$ and $28 \mathrm{~S}$ ribosomal DNA sequence analysis," Mycologia, vol. 89, no. 1, pp. 48-65, 1997.

[12] V. Kagan-Zur and N. Roth-Bejerano, "Desert truffles," Fungi, vol. 1, pp. 32-37, 2008.

[13] A. A. A. Al-Laith, "Antioxidant components and antioxidant/antiradical activities of desert truffle (Tirmania nivea) from various Middle Eastern origins," Journal of Food Composition and Analysis, vol. 23, no. 1, pp. 15-22, 2010.

[14] Q. A. Mandeel and A. A. A. Al-Laith, "Ethnomycological aspects of the desert truffle among native Bahraini and nonBahraini peoples of the Kingdom of Bahrain," Journal of Ethnopharmacology, vol. 110, no. 1, pp. 118-129, 2007.

[15] S. Wang and M. F. Marcone, "The biochemistry and biological properties of the world's most expensive underground edible mushroom: truffles," Food Research International, vol. 44, no. 9, pp. 2567-2581, 2011.

[16] G. Hussain and I. M. Al-Ruqaie, "Occurrence, chemical composition and nutritional value of truffles: an overview," Pakistan Journal of Biological Sciences, vol. 2, no. 2, pp. 510-514, 1999.

[17] W. N. Sawaya, A. Al-Shalhat, A. Al-Sogair, and M. Mohammad, "Chemical composition and nutritive value of truffles of Saudi Arabia," Journal of Food Science, vol. 50, pp. 450-453, 1985.

[18] P. C.-K. Cheung, "Dietary fibre content and composition of some edible fungi determined by two methods of analysis," Journal of the Science of Food and Agriculture, vol. 72, pp. 255260, 1997.

[19] J. Vetter and I. Rimóczi, "Crude, digestible and nondigestible proteins in fruit bodies of Pleurotus ostreatus (oyster mushroom)," Zeitschrift für Lebensmittel-Untersuchung und -Forschung, vol. 197, no. 5, pp. 427-428, 1993.

[20] D. Nedelcheva, D. Antonova, S. Tsvetkova et al., "TLC and GC-MS probes into the fatty acid composition of some Lycoperdaceae mushrooms," Journal of Liquid Chromatography and Related Technologies, vol. 30, no. 18, pp. 2717-2727, 2007.
[21] T. Řezanka, O. A. Rozentsvet, and V. M. Dembitsky, "Characterization of the hydroxy fatty acid content of Basidiomycotina," Folia Microbiologica, vol. 44, no. 6, pp. 635-641, 1999.

[22] M. A. Fraatz and H. Zorn, "Fungal flavours," in The Mycota: Industrial Applications, vol. 10, pp. 249-268, Springer, Berlin, Germany, 2010.

[23] R. Splivallo, "Biological significance of truffle secondary metabolites," in Secondary Metabolites in Soil Ecology, vol. 14 of Soil Biology, pp. 141-165, Springer, Berlin, Germany, 2008.

[24] S.-Y. Tsai, S.-J. Huang, S.-H. Lo, T.-P. Wu, P.-Y. Lian, and J.L. Mau, "Flavour components and antioxidant properties of several cultivated mushrooms," Food Chemistry, vol. 113, no. 2, pp. 578-584, 2009.

[25] M. Nyegue, P. A. Zollo, J. Bessiére, and S. Rapior, "Volatile components of fresh Pleurotus ostreatus and Termitomyces shimperi from Cameroon," Journal of Essential Oil Bear Plants, vol. 6, pp. 153-160, 2003.

[26] A. Villares, A. García-Lafuente, E. Guillamón, and Á. Ramos, "Identification and quantification of ergosterol and phenolic compounds occurring in Tuber spp. truffles," Journal of Food Composition and Analysis, vol. 26, no. 1-2, pp. 177-182, 2012.

[27] M. A. Murcia, M. Martínez-Tomé, A. M. Jiménez, A. M. Vera, M. Honrubia, and P. Parras, "Antioxidant activity of edible fungi (truffles and mushrooms): losses during industrial processing," Journal of Food Protection, vol. 65, no. 10, pp. 1614-1622, 2002.

[28] M. A. Al-Marzooky, "Truffles in eye disease," in Proceedings of the International Islamic Medicine, pp. 353-357, Kuwait, 1981.

[29] S. Janakat, S. Al-Fakhiri, and A.-K. Sallal, "A promising peptide antibiotic from Terfezia claveryi aqueous extract against Staphylococcus aureus in vitro," Phytotherapy Research, vol. 18, no. 10, pp. 810-813, 2004.

[30] S. M. Janakat, S. M. Al-Fakhiri, and A.-K. J. Sallal, "Evaluation of antibacterial activity of aqueous and methanolic extracts of the truffle Terfezia claveryi against Pseudomonas aeruginosa," Saudi Medical Journal, vol. 26, no. 6, pp. 952-955, 2005.

[31] S. Dib-Bellahouel and Z. Fortas, "Antibacterial activity of various fractions of ethyl acetate extract from the desert truffle, Tirmania pinoyi, preliminarily analyzed by gas chromatographymass spectrometry (GC-MS)," African Journal of Biotechnology, vol. 10, no. 47, pp. 9694-9699, 2011.

[32] H. P. Molitoris, "Mushrooms in medicine," Folia Microbiologica, vol. 39, no. 2, pp. 91-98, 1994.

[33] S. Wasser, "Medicinal mushrooms as a source of antitumor and immunomodulating polysaccharides," Applied Microbiology and Biotechnology, vol. 60, no. 3, pp. 258-274, 2003.

[34] M.-F. Moradali, H. Mostafavi, S. Ghods, and G.-A. Hedjaroude, "Immunomodulating and anticancer agents in the realm of macromycetes fungi (macrofungi)," International Immunopharmacology, vol. 7, no. 6, pp. 701-724, 2007.

[35] V. E. C. Ooi, "Antitumor and immunomodulatory activities of mushroom polysaccharides," in Mushrooms as Functional Food, pp. 147-198, John Wiley \& Sons, New York, NY, USA, 2008.

[36] A. Zong, H. Gao, and F. Wang, "Anticancer polysaccharides from natural sources: a review of recent research," Carbohydrate Polymers, vol. 90, pp. 1395-1410, 2012.

[37] T. Ikekawa, N. Uehara, Y. Maeda, M. Nakanishi, and F. Fukuoka, "Antitumor activity of aqueous extracts of edible mushrooms," Cancer Research, vol. 29, no. 3, pp. 734-735, 1969.

[38] S. Badalyan, "Medicinal aspects of edible ectomycorrhizal mushrooms," in Edible Ectomycorrhizal Mushrooms, pp. 317334, Springer, Berlin, Germany, 2012. 
[39] M. Zhang, S. W. Cui, P. C. K. Cheung, and Q. Wang, "Antitumor polysaccharides from mushrooms: a review on their isolation process, structural characteristics and antitumor activity," Trends in Food Science and Technology, vol. 18, no. 1, pp. 4-19, 2007.

[40] H. El Enshasy, P. Maftoun, and R. Abd Malek, "Pleuran: immunomodulotor polysaccharide from pleurotus ostreatus, structure, production and application," in Mushrooms: Types, Properties and Nutrition, pp. 153-172, Nova Publisher, New York, NY, USA, 2012.

[41] H. Sakagami, T. Aoki, A. Simpson, and S.-I. Tanuma, "Induction of immunopotentiation activity by a protein-bound polysaccharide, PSK," Anticancer Research, vol. 11, no. 2, pp. 993-999, 1991.

[42] M. Okuzawa, H. Shinohara, T. Kobayashi, M. Iwamoto, M. Toyoda, and N. Tanigawa, "PSK, a protein-bound polysaccharide, overcomes defective maturation of dendritic cells exposed to tumor-derived factors in vitro," International Journal of Oncology, vol. 20, no. 6, pp. 1189-1195, 2002.

[43] G. Franz, "Polysaccharides in pharmacy: current applications and future concepts," Planta Medica, vol. 55, no. 6, pp. 493-497, 1989.

[44] J. J. Zhong and J. P. H. Xiao, "Secondary metabolites from higher fungi: discovery, bioactivity, and bioproduction," Advances in Biochemical Engineering and Biotechnology, vol. 113, pp. 79-150, 2009.

[45] S. Janakat and M. Nassar, "Hepatoprotective activity of desert truffle (Terfezia claveryi) in comparison with the effect of Nigella sativa in the rat," Pakistan Journal of Nutrition, vol. 9, no. 1, pp. 52-56, 2010.

[46] K. D. Hyde, A. H. Bahkali, and M. A. Moslem, "Fungi-an unusual source for cosmetics," Fungal Diversity, vol. 43, pp. 19, 2010.

[47] D. L. Hawksworth, "The magnitude of fungal diversity: the 1.5 million species estimate revisited," Mycological Research, vol. 105, no. 12, pp. 1422-1432, 2001.

[48] O. V. Oyetayo, "Medicinal uses of mushrooms in Nigeria: towards full and sustainable exploitation," African Journal of Traditional, Complementary and Alternative Medicines, vol. 8, no. 3, pp. 267-274, 2011.

[49] M. Heinrich, "Ethnopharmacology and drug discovery," in Comprehensive Natural Products II: Chemistry and Biology, Development \& Modification of Bioactivity, R. Verpoorte, Ed., vol. 3, pp. 351-381, Elsevier, Oxford, UK, 2010.

[50] P. Zhu, "The present status and prospects of medicinal fungal research and development in China," in Proceeding of The 5th International Medicinal Mushroom Conference, pp. 26-33, Nantong, China, 2009.

[51] E. A. Akpaja, O. S. Isikhuemhen, and J. A. Okhuoya, "Ethnomycology and usage of edible and medicinal mushrooms among the Igbo people of Nigeria," International Journal of Medicinal Mushrooms, vol. 5, no. 3, pp. 313-319, 2003.

[52] B. A. Oso, "Mushrooms and the Yoruba people of Nigeria," Mycologia, vol. 67, no. 2, pp. 311-319, 1975.

[53] J. M. Watt and M. G. Breyer-Brandwijk, The Medicinal and Poisonous Plants of Southern and Eastern Africa, Livingstone, London, UK, 2nd edition, 1962.

[54] B. E. van Wyk, B. van Oudtshoorn, and N. Gericke, Medicinal Plants of South Africa, Briza Publications, Pretoria, South Africa, 1997.

[55] H. D. Neuwinger, African Traditional Medicine. A Dictionary of Plant Use and Application, Medpharm Scientific Publication, Stuttgart, Germany, 2000.
[56] S. T. Chang and K. Mshigeni, Mushrooms and Human Health: Their Growing Significance as Potent Dietary Supplements, University of Namibia, Windhoek, Namibia, 2001.

[57] B. A. Oso, "Mushrooms in yoruba mythology and medicinal practices," Economic Botany, vol. 31, no. 3, pp. 367-371, 1977.

[58] C. N. Ezekiel, M. Sulyok, J. C. Frisvad et al., "Fungal and mycotoxin assessment of dried edible mushroom in Nigeria," International Journal of Food Microbiology, vol. 162, pp. 231-236, 2013.

[59] D. D. Tibuhwa, "Folk taxonomy and use of mushrooms in communities around Ngorongoro and Serengeti National Park, Tanzania," Journal of Ethnobiology and Ethnomedicine, vol. 8, pp. 36-45, 2012.

[60] S. J. M. Mdachi, M. H. H. Nkunya, V. A. Nyigo, and I. T. Urasa, "Amino acid composition of some Tanzanian wild mushrooms," Food Chemistry, vol. 86, no. 2, pp. 179-182, 2004.

[61] M. Kamatenesi-Mugisha and H. Oryem-Origa, "Medicinal plants used to induce labour during childbirth in western Uganda," Journal of Ethnopharmacology, vol. 109, no. 1, pp. 1-9, 2007.

[62] C. Beiersmann, A. Sanou, E. Wladarsch, M. de Allegri, B. Kouyaté, and O. Müller, "Malaria in rural Burkina Faso: local illness concepts, patterns of traditional treatment and influence on health-seeking behaviour," Malaria Journal, vol. 6, pp. 106114, 2007.

[63] G. Samorini, "The oldest presentations of hallucinogenic mushrooms in the world (Sahara desert, 9000-7000 B.P.)," Integration, vol. 2, no. 3, pp. 69-78, 1992.

[64] L. V. Griensven, "Mushrooms, must action be taken?" in Proceeding of The 5th International Medicinal Mushroom Conference, pp. 407-412, Nantong, China, 2009.

[65] S. M. Ayodele, E. O. Akpaja, and Y. Adamu, "Some edible and medicinal mushrooms found in Igala land in Nigeria and their sociocultural and ethnomycological uses," in Proceeding of The 5th International Medicinal Mushroom Conference, pp. 526-531, Nantong, China, 2009.

[66] J. L. Harley and S. E. Smith, Mycorrhizal Symbiosis, Academic Press, London, UK, 1983.

[67] R. Saltarelli, P. Ceccaroli, P. Cesari, E. Barbieri, and V. Stocchi, "Effect of storage on biochemical and microbiological parameters of edible truffle species," Food Chemistry, vol. 109, no. 1, pp. 8-16, 2008.

[68] J. M. Trappe and A. W. Claridge, “The hidden life of: truffles," The Scientific American, vol. 302, no. 4, pp. 78-84, 2010.

[69] L. Riousset, G. Riousset, G. Chevalier, and M. C. Bardet, Truffes d'Europe et de Chine, INRA, Paris, France, 2001.

[70] L. Culleré, V. Ferreira, M. E. Venturini, P. Marco, and D. Blanco, "Potential aromatic compounds as markers to differentiate between Tuber melanosporum and Tuber indicum truffles," Food Chemistry, vol. 141, no. 1, pp. 105-110, 2013.

[71] J. M. Trappe, A. W. Claridge, D. L. Claridge, and L. Liddle, "Desert truffles of the Australian outback: ecology, ethnomycology, and taxonomy," Economic Botany, vol. 62, no. 3, pp. 497506, 2008.

[72] A. A. Ahmed, M. A. Mohammed, and M. A. Hamid, "Libyan truffles Terfezia boudieri chatin chemical composition and toxicity," Journal of Food Science, vol. 46, pp. 327-329, 1981.

[73] E. A. Omer, D. L. Smith, K. V. Wood, and B. S. El-Menshawi, "The volatiles of desert truffle: Tirmania nivea," Plant Foods for Human Nutrition, vol. 45, no. 3, pp. 247-249, 1994. 
[74] H. A. Bokhary and S. Parvez, "Soil mycoflora from trufflè native areas of Saudi Arabia," Mycopathologia, vol. 118, no. 2, pp. 103107, 1992.

[75] M. A. Hannan, A. A. Al-Dakan, H. Y. Aboul-Enein, and A. A. Al-Othaimeen, "Mutagenic and antimutagenic factor(s) extracted from a desert mushroom using different solvents," Mutagenesis, vol. 4, no. 2, pp. 111-114, 1989.

[76] R. Stanikunaite, S. I. Khan, J. M. Trappe, and S. A. Ross, "Cyclooxygenase-2 inhibitory and antioxidant compounds from the truffle Elaphomyces granulatus," Phytotherapy Research, vol. 23, no. 4, pp. 575-578, 2009.

[77] S. Patel, "Food, health and agricultural importance of truffles: a review of current scientific literature," Current Trends in Biotechnology and Pharmacy, vol. 6, no. 1, pp. 15-27, 2012.

[78] R. Stanikunaite, J. M. Trappe, S. I. Khan, and S. A. Ross, "Evaluation of therapeutic activity of hypogeous ascomycetes and basidiomycetes from North America," International Journal of Medicinal Mushrooms, vol. 9, no. 1, pp. 7-14, 2007.

[79] L. G. J. Ackerman, P. J. vanWyk, and L. M. du Plassis, "Some aspects of the composition of the Kalahari truffle of N'abba," South African Food Review, vol. 2, pp. 145-147, 1975.

[80] W. F. O. Marasas and J. M. Trappe, "Notes on Southern African tuberales," Bothalia, vol. 11, pp. 139-141, 1973.

[81] I. B. Pole-Evans, "Notes on the genus Terfezia. A truffle from Kalahari," Transactions of the Royal Society of Africa, vol. 7, pp. 117-118, 1918.

[82] J. M. Trappe, A. W. Claridge, D. Arora, and W. A. Smit, "Desert truffles of the African Kalahari: ecology, ethnomycology, and taxonomy," Economic Botany, vol. 62, no. 3, pp. 521-529, 2008.

[83] M. S. Awameh and A. Al-Sheikh, "Laboratory and field study of four kinds of truffle (Kamah), Terfezia and Tirmania, for cultivation," Mushroom Science, vol. 10, pp. 507-517, 1978.

[84] O. Mattirolo, "Osservazioni supra due ipogea della Cirenaica e considerazione intorno ai generi Tirmania e Terfezia," Memoria Reale Accademia Nazionale Dei Lincei Ser, vol. 5, pp. 544-568, 1922.

[85] A. N. Al-Rahmmah, Truffle of Deserts and Jungles, King Saud University Publication, Riyadh, Saudi Arabia, 2001, (Arabic).

[86] Y. Ferdman, S. Aviram, N. Roth-Bejerano, J. M. Trappe, and V. Kagan-Zur, "Phylogenetic studies of Terfezia pfeilii and Choiromyces echinulatus (Pezizales) support new genera for southern African truffles: Kalaharituber and Eremiomyces," Mycological Research, vol. 109, no. 2, pp. 237-245, 2005.

[87] A. Salam, Z. Fortas, M. Neffati, L. Khabar, and A. Boudabbous, "Etude taxonomique de quelques Ascomycota hypogés (Terfeziaceae) de la Tunisie méridionale," Bulletin of Society of Mycology France, vol. 122, pp. 187-195, 2006.

[88] A. M. Al-Sheik and J. M. Trappe, "Desert truffles: the genus Tirmania," Transactions of the British Mycological Society, vol. 81, pp. 83-90, 1983.

[89] I. Sbissi, M. Neffati, A. Boudabous, C. Murat, and M. Gtari, "Phylogenetic affiliation of the desert truffles Picoa juniperi and Picoa lefebvrei," Antonie van Leeuwenhoek, International Journal of General and Molecular Microbiology, vol. 98, no. 4, pp. 429436, 2010.

[90] M. Härkönen, T. Saarimäki, and L. Mwasumbi, “Tanzanian mushrooms and their uses 4 . Some raddish edible and poisonous Amanita species," Karstenia, vol. 34, pp. 47-60, 1994.

[91] B. Buyck, "The edible mushrooms of Madagascar: an evolving enigma," Economic Botany, vol. 62, no. 3, pp. 509-520, 2008.
[92] A. J. Masuka, "Community management, harvesting and trade of edible mushrooms in the miombo ecoregion of eastern and southern Africa," Tech. Rep., FAO, Harare, Zimbabwe, 2002.

[93] D. N. Pegler and G. D. Piearce, "The edible mushrooms of Zambia," Kew Bulletin, vol. 35, pp. 475-491, 1980.

[94] J. Degreef, F. Malaisse, J. Rammeloo, and E. Baudart, "Edible mushrooms of the Zambezian woodland area. A nutritional and ecological approach," Biotechnology, Agronomy, Society and Environment, vol. 1, no. 3, pp. 221-231, 1997.

[95] G. Parent and D. Thoen, "Food value of edible Mushrooms from Upper-Shaba region," Economic Botany, vol. 31, no. 4, pp. 436445, 1977.

[96] N. Tuno, "Mushroom utilization by the Majangir, an Ethiopian tribe," Mycologist, vol. 15, no. 2, pp. 78-79, 2001.

[97] K. M. L. Guissou, A. M. Lykke, P. Sankara, and S. Guinko, "Declining wild mushroom recognition and usage in Burkina Faso," Economic Botany, vol. 62, no. 3, pp. 530-539, 2008. 


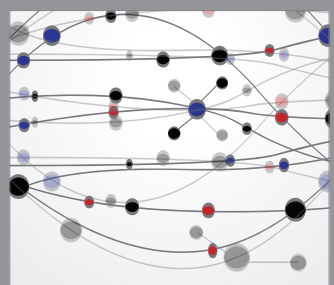

The Scientific World Journal
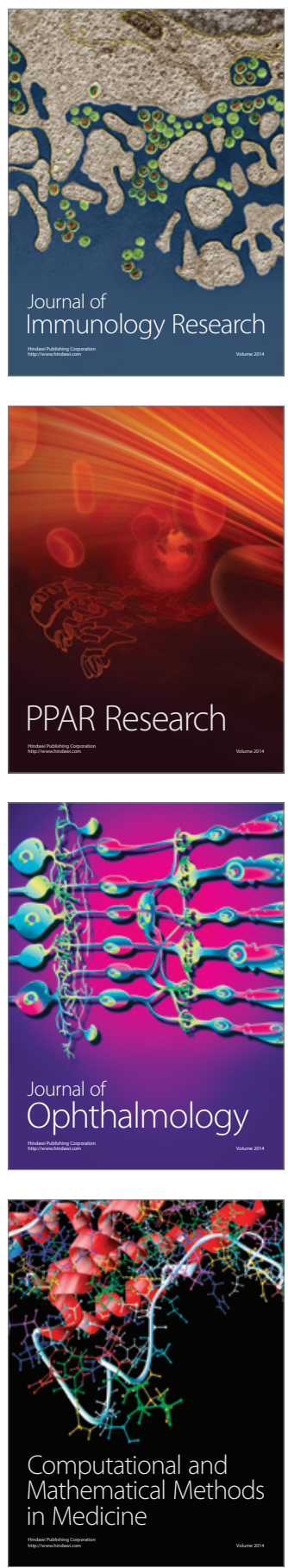

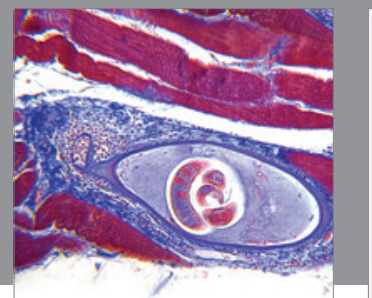

Gastroenterology

Research and Practice
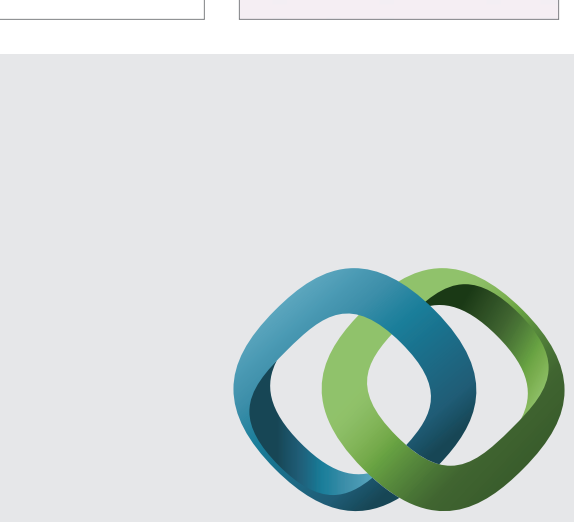

\section{Hindawi}

Submit your manuscripts at

http://www.hindawi.com
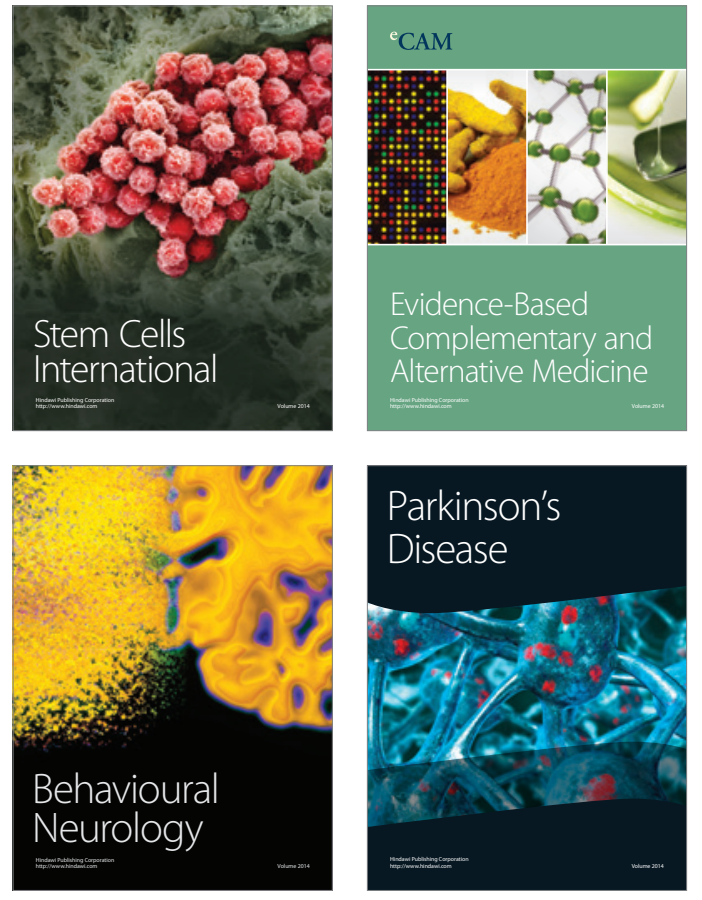
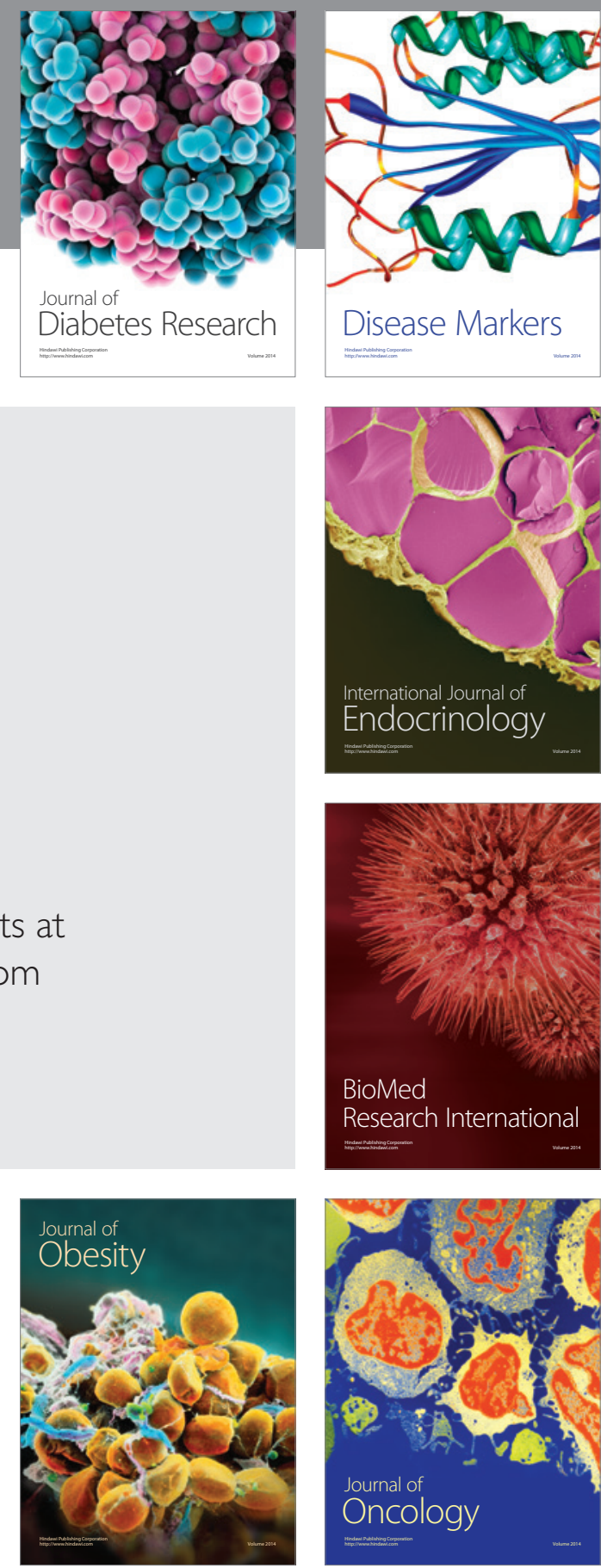

Disease Markers
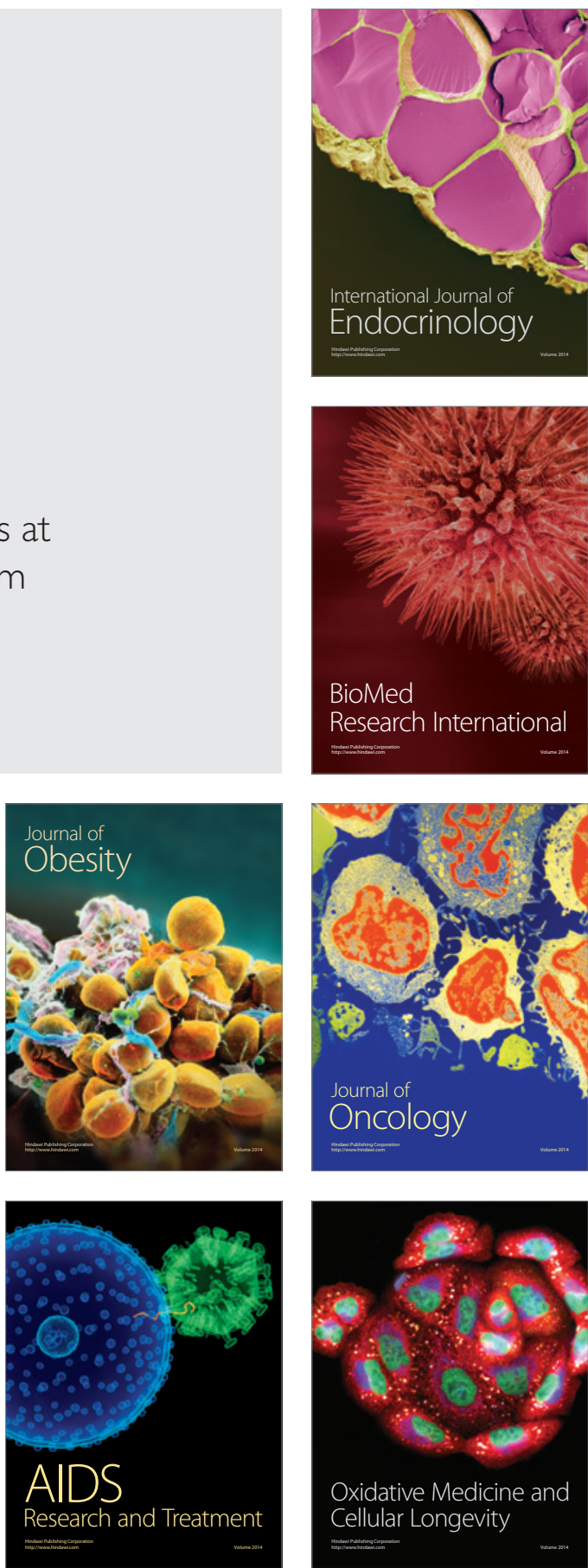